Article

\title{
Isolation and Investigation of Potential Non-Saccharomyces Yeasts to Improve the Volatile Terpene Compounds in Korean Muscat Bailey A Wine
}

\author{
Sae-Byuk Lee ${ }^{1}$ and Heui-Dong Park ${ }^{1,2, *}$ \\ 1 School of Food Science and Biotechnology, Kyungpook National University, 80 Daehakro, \\ Daegu 41566, Korea; lsbyuck@nate.com \\ 2 Institute of Fermentation Biotechnology, Kyungpook National University, 80 Daehakro, Daegu 41566, Korea \\ * Correspondence: hpark@knu.ac.kr; Tel.: +82-53-950-5774
}

Received: 31 August 2020; Accepted: 6 October 2020; Published: 8 October 2020

check for updates

\begin{abstract}
The Muscat Bailey A (MBA) grape, one of the most prominent grape cultivars in Korea, contains considerable amounts of monoterpene alcohols that have very low odor thresholds and significantly affect the perception of wine aroma. To develop a potential wine starter for Korean MBA wine, nine types of non-Saccharomyces yeasts were isolated from various Korean food materials, including nuruk, Sémillon grapes, persimmons, and Muscat Bailey A grapes, and their physiological, biochemical, and enzymatic properties were investigated and compared to the conventional wine fermentation strain, Saccharomyces cerevisiae W-3. Through API ZYM analysis, Wickerhamomyces anomalus JK04, Hanseniaspora vineae S7, Hanseniaspora uvarum S8, Candida railenensis S18, and Metschnikowia pulcherrima S36 were revealed to have $\beta$-glucosidase activity. Their activities were quantified by culturing in growth medium composed of different carbon sources: $2 \%$ glucose, $1 \%$ glucose $+1 \%$ cellobiose, and $2 \%$ cellobiose. W. anomalus JK04 and M. pulcherrima S36 showed the highest $\beta$-glucosidase activities in all growth media; thus, they were selected and utilized for MBA wine fermentation. MBA wines co-fermented with non-Saccharomyces yeasts (W. anomalus JK04 or M. pulcherrima S36) and S. cerevisiae W-3 showed significantly increased levels of linalool, citronellol, and geraniol compared to MBA wine fermented with S. cerevisiae W-3 (control). In a sensory evaluation, the flavor, taste, and overall preference scores of the co-fermented wines were higher than those for the control wine, suggesting that W. anomalus JK04 and M. pulcherrima S36 are favorable wine starters for improving Korean MBA wine quality.
\end{abstract}

Keywords: non-Saccharomyces yeasts; MBA wine; Fermentation; $\beta$-glucosidase; volatile aromatic compound

\section{Introduction}

The properties of yeast and its metabolites are affected by several environmental factors, which have long been utilized in various fields, such as enzymology, baking, alcoholic beverage production, and pharmacology [1]. In particular, Saccharomyces cerevisiae, the most well-known and well-studied yeast, is typically used for winemaking because it can survive under high ethanol concentrations, ferments faster than other strains, and secretes toxic compounds to inhibit the growth of undesirable microorganisms during fermentation [1,2]. Although S. cerevisiae has many advantages for alcohol fermentation, the potential application of various non-Saccharomyces yeasts has also been explored. These strains are widely found in nature and mainly grow during the initial step of wine fermentation, consequently affecting the taste and aroma of wine by producing volatile aromatic compounds such as esters, monoterpenes, higher alcohols, and acids [3-5]. For example, Hanseniaspora guilliermondii 
and Wickerhamomyces anomalus (formerly known as Pichia anomala) have been reported to exhibit acetate ester-forming activities, resulting in an acetate ester-enriched wine during fermentation by co-culture with S. cerevisiae $[3,4,6]$. Issatchenkia terricola, Pichia kudriavzevii, W. anomalus, H. uvarum, Metschnikowia pulcherrima and Dekkera bruxellensis also enhance the aromatic properties of wine by releasing $\beta$-glucosidase, which hydrolyzes the glucosidic bonds from various aglycone structures to monoterpenes, precursors of aromatic compounds [7-10]. Recently, some of the major starter companies have commercialized non-Saccharomyces yeasts for winemaking, thereby contributing to the improvement and diversification of commercial wine products [11].

Campbell Early and Muscat Bailey A (MBA) grapes are the most commonly cultivated varieties in Korean winemaking [12]. Campbell Early grapes contain high malic acid contents caused by early harvesting, which enhance the grape color. Chaptalization of Campbell Early grapes is required for winemaking due to their low sugar content (14-15 Brix) [13,14]. The MBA grape, a hybrid of Muscat Hamburg and Bailey cultivars, contains less acidity and a higher sugar content (18-21 Brix) compared to Campbell Early grapes, suggesting that MBA grapes are more suitable for winemaking as they do not require chaptalization [15]. Furthermore, Muscat grape varieties contain superior monoterpene alcohols, such as linalool, geraniol, nerol, citronellol, and $\alpha$-terpineol [16-18]. A small increase in these compounds during fermentation can significantly affect the wine aroma due to the low odor thresholds [16-18]. Despite the potential of MBA grapes against volatile terpene compounds, Korean researchers have focused on the processing strategies irrelevant to wine aroma, such as freeze-concentration, pectinase treatment, blending with Aronia, and the reduction of acetaldehyde, methanol, and fusel oils [15,19-21]. Thus, the investigation of the ability of non-Saccharomyces yeasts to enhance volatile terpene compounds in MBA wine will contribute to increased competitiveness for Korean wine.

The objective of this study is to select non-Saccharomyces yeast isolates as candidate wine starters for improving the aroma of Korean MBA wine. Nine types of non-Saccharomyces yeasts were isolated from various Korean food materials, and their physiological and biochemical characteristics were investigated for comparison among isolates. In addition, the enzymatic characteristics and $\beta$-glucosidase activities of each strain were examined to evaluate the potential for aroma-forming activity. Finally, various fermentation characteristics and the volatile aromatic profiling of MBA wine fermented by co-culture with non-Saccharomyces yeasts and S. cerevisiae strain W-3 (as a control) were investigated.

\section{Materials and Methods}

\subsection{Strains and Isolation}

Saccharomyces cerevisiae W-3, an industrial wine yeast strain, was utilized as a control for all experiments. Wickerhamomyces anomalus JK04 and Torulaspora delbrueckii JK08, isolated from nuruk and stored in the laboratory, were used as non-Saccharomyces comparison strains [22]. Seven other strains of non-Saccharomyces yeasts were isolated from Sémillon grapes, persimmons, and MBA grapes cultivated in Korea. The non-Saccharomyces yeasts were isolated by crushing the food materials, followed by immersion in $0.9 \% \mathrm{NaCl}$ solution. The samples were then sequentially diluted, and the aqueous solution was spread onto yeast peptone dextrose (YPD) agar plates and incubated at $30^{\circ} \mathrm{C}$ for 2 days. All isolates were selected at random.

\subsection{Polymerase Chain Reaction (PCR) and PCR-Restriction Fragment Length Polymorphism (RFLP)}

Genomic DNA, used as the PCR template, was isolated from yeast cells grown in YPD medium for $24 \mathrm{~h}$ as described by Kaiser and Philippsen [23,24]. Internal transcribed spacer (ITS) region oligonucleotide primer sets (ITS1, 5'-CAT TTA GAG GAA CTA AAA GTC G-3' and ITS4, 5'-CCT CCG CTT ATT GAT ATG C-3'), synthesized by Bioneer Co. (Chongwon, Korea), were used for PCR and PCR-RFLP analysis [25]. PCR was performed in a $50 \mu \mathrm{L}$ reaction volume using TaKaRa Taq DNA polymerase (Takara Shuzo Co., Otsu, Japan) with a GENE cycler (Bio-Rad Co., Richmond, CA, 
USA). The PCR mixture consisted of $1 \mu \mathrm{g}$ yeast genomic DNA, 10 pmol of each primer, $1 \mathrm{U}$ Taq DNA polymerase, $0.25 \mathrm{mM}$ of each dNTP, $10 \mathrm{mM}$ Tris- $\mathrm{HCl}$ (pH 8.3), $50 \mathrm{mM} \mathrm{KCl}$, and $2.5 \mathrm{mM} \mathrm{MgCl}$. The PCR cycle program for DNA amplification comprised one cycle at $94{ }^{\circ} \mathrm{C}$ for $3 \mathrm{~min}, 35$ cycles of $94{ }^{\circ} \mathrm{C}$ for $45 \mathrm{~s}, 55^{\circ} \mathrm{C}$ for $60 \mathrm{~s}, 72{ }^{\circ} \mathrm{C}$ for $60 \mathrm{~s}$, and one cycle of $72{ }^{\circ} \mathrm{C}$ for $10 \mathrm{~min}$. For PCR-RFLP, excess dNTPs and primers were removed from the PCR products using a PCR purification kit (Solgent, Daejeon, Korea). Then, appropriate amounts of amplicons were digested at $37^{\circ} \mathrm{C}$ for $1 \mathrm{~h}$ with $0.5 \mu \mathrm{L}$ of Hinf I, Hae III, and Hpa I endonucleases (Takara Shuzo Co., Otsu, Japan). DNA fragments were resolved on a $2.0 \%$ agarose gel according to standard methods [26], and a $100 \mathrm{bp}$ Plus DNA Ladder (Solgent, Daegeon, Korea) was used as a marker to check the DNA size. To identify the isolated yeasts, the nucleotide sequences of the ITS I-5.8S-ITS II region were compared with those available in the GenBank database using the BLAST feature of the National Center for Biotechnology Information database http://blast.ncbi.nlm.nih.gov/Blast.cgi [27].

\subsection{Enzymatic Activity and $\beta$-Glucosidase Activity}

An API ZYM kit was used to analyze the enzymatic activities of the non-Saccharomyces yeasts. All strains were diluted to 5.0-6.0 McFarland standard with API suspension medium, inoculated into API ZYM test strips, and then incubated at $37^{\circ} \mathrm{C}$ for $4 \mathrm{~h}$. After the addition of one drop of ZYM reagent, reagents $A$ and $B$ from the kit were serially added to each strip and the strips were incubated for $5 \mathrm{~min}$, allowing for colorimetric analysis [28]. Enzyme activity was classified from 0 (no activity) to 5 (maximum activity) using the API ZYM color reaction chart. Strains showing $\beta$-glucosidase activity were then further selected for culture in three kinds of media at $30^{\circ} \mathrm{C}$ for $72 \mathrm{~h}$ to determine the effect of different types of carbon source on the $\beta$-glucosidase activity: YPD ( $1 \%$ yeast extract, $2 \%$ peptone, and $2 \%$ glucose), YPDC (1\% yeast extract, $2 \%$ peptone, $1 \%$ glucose, and $1 \%$ cellobiose), and YPC ( $1 \%$ yeast extract, $2 \%$ peptone, and $2 \%$ cellobiose). Cells were collected every $12 \mathrm{~h}$ by centrifugation at $10,000 \times g$ for $3 \mathrm{~min}$, and the enzyme activity of the supernatant was quantified. $\beta$-glucosidase activity was analyzed by measuring the amount of $p$-nitrophenyl- $\beta$-D-glucopyranoside ( $p$ NPG, Sigma, St. Louis, MO, USA) according to a slight modification of Swangkeaw's method [8]. The centrifuged supernatant $(0.1 \mathrm{~mL})$ was mixed with $0.2 \mathrm{~mL}$ of $4 \mathrm{mM} p \mathrm{NPG}$ solution and $0.2 \mathrm{~mL}$ of $0.1 \mathrm{M}$ citrate phosphate buffer ( $\mathrm{pH}$ 5.0). The mixture was incubated at $30{ }^{\circ} \mathrm{C}$ for $30 \mathrm{~min}$ and the reaction was subsequently stopped by adding $2.0 \mathrm{~mL}$ of $2 \mathrm{M}$ sodium carbonate. The $p$ NPG released from this mixture was measured spectrophotometrically at $405 \mathrm{~nm}$. One unit $(\mathrm{U})$ of enzyme activity was defined as the amount of enzyme that released $1 \mu \mathrm{mol}$ of $p$ NPG per minute under the experimental conditions.

\subsection{Physiological Characteristics}

Carbon fermentation and assimilation were analyzed and compared according to a standard yeast identification method [29]. The ability of carbon fermentation was confirmed by carbon dioxide gas filled in Durham tubes of $5 \mathrm{~mL}$ liquid medium containing $4.5 \mathrm{~g} / \mathrm{L}$ yeast extract, $7.5 \mathrm{~g} / \mathrm{L}$ peptone, and $20 \mathrm{~g} / \mathrm{L}$ sugars, including D-glucose, D-galactose, maltose, sucrose, lactose, and trehalose (except for raffinose, where $4 \%$ is commonly used because some strains use only part of this molecule). Each yeast was cultured at $25^{\circ} \mathrm{C}$ for 14 days without shaking. The results were scored depending on the time taken to fill the insert with gas and the amount accumulating, as follows: + , strongly positive, insert filled within 7 days; $d$, delayed positive, insert rapidly filled, but only after more than 7 days; s, slowly positive, insert slowly filled after more than 7 days; $w$, weakly positive, the insert was not fully filled with gas (less than one-third full is often considered weak, whereas greater than one-third full is positive); -, negative, no accumulation of gas in the insert. To determine the ability of carbon assimilation, each yeast cell was cultured in $5 \mathrm{~mL}$ YNB broth $(6.7 \mathrm{~g} / \mathrm{L}$ yeast nitrogen base, and $20 \mathrm{~g} / \mathrm{L}$ sugars except for raffinose, which was $4 \%$ ) at $30^{\circ} \mathrm{C}$ for 14 days. The 43 carbon compounds used in this study were as follows: hexoses (D-glucose, D-galactose, and L-sorbose), disaccharides (cellobiose, lactose, maltose, melibiose, sucrose, and trehalose), trisaccharides (melezitose and raffinose), polysaccharides (inulin and soluble starch), pentoses (D-arabinose, L-arabinose, D-ribose, L-rhamnose, and D-xylose), alcohols (erythritol, galactitol, 
D-glucitol, glycerol, myo-inositol, D-mannitol, ribitol, ethanol, methanol, xylitol, and L-arabinitol), organic acids (citrate, DL-lactate, succinate, and D-gluconate), glycosides ( $\alpha$-methyl-D-glucoside, salicin, and arbutin), and other compounds (D-glucosamine hydrochloride, $\mathrm{N}$-acetyl-D-glucosamine, hexadecane, 2-keto-D-gluconate, 5-keto-D-gluconate, saccharate, and D-glucuronate). The results were presented as follows: +, positive, completely grown after 1 week; d, delayed positive, rapidly grown but only after 2 weeks; s, slow positive, slowly grown over 2 weeks; w, weak positive, slightly grown; - , negative, no growth.

\subsection{Environmental Tolerance and Fermentation Rates}

The strains' tolerances to several environmental stresses, including glucose, ethanol, acid, and sulfur dioxide $\left(\mathrm{SO}_{2}\right)$, were determined by culturing the isolates on modified YPD broth, in which the media were adjusted or supplemented to $20 \%$ and $50 \%$ glucose; $8 \%$ and $12 \%$ ethanol; $\mathrm{pH} 2$ and 4; and 200 and $500 \mathrm{mg} / \mathrm{L}$ potassium metabisulfite $\left(\mathrm{K}_{2} \mathrm{~S}_{2} \mathrm{O}_{5}\right)$. The ethanol and $\mathrm{SO}_{2}$ solutions were filter-sterilized before addition to the YPD broth. Each strain was first cultured in $5 \mathrm{~mL}$ YPD at $30{ }^{\circ} \mathrm{C}$ for $16 \mathrm{~h}$, then inoculated to the respective modified YPD broth with initial cell density of 0.5 (OD $600 \mathrm{~nm}$ ) and incubated at $30{ }^{\circ} \mathrm{C}$ for $48 \mathrm{~h}$. The $\mathrm{pH}$ was adjusted by the addition of hydrochloride ( $\mathrm{HCl}$ ) solution. Cell suspensions were quantified spectrophotometrically at $600 \mathrm{~nm}$.

The fermentation rate was analyzed to compare the fermentability of each strain incubated in $100 \mathrm{~mL}$ YPD broth consisting of $20 \%$ glucose at $20{ }^{\circ} \mathrm{C}$ without shaking until the fermentation was complete. A water-trap apparatus containing concentrated $\mathrm{H}_{2} \mathrm{SO}_{4}$ was attached to the top of each flask to trap the water evaporating from the flask during fermentation. The amount of $\mathrm{CO}_{2}$ produced was indirectly measured as the decrease in the weight of the whole flask. The fermentation ratio was expressed as the percentage of the amount of $\mathrm{CO}_{2}$ produced according to the theoretical $\mathrm{CO}_{2}$ production from glucose due to ethanol fermentation [30]. The fermentation rate was calculated as follows:

$$
\left(R_{\mathrm{CO} 2} \times \frac{M_{G l u}}{M_{\mathrm{CO} 2}}\right) \times \frac{1}{W_{G l u}} \times 100
$$

where $R_{\mathrm{CO} 2}$ is the weight of reduced carbon dioxide during alcohol fermentation, $M_{\mathrm{Glu}}$ and $M_{\mathrm{CO} 2}$ are the molecular weights of glucose and carbon dioxide, respectively, and $W_{G l u}$ is the initial weight of the glucose in the YPD broth (20 g).

\subsection{Wine Fermentation}

Muscat Bailey A grapes, cultivated in Yeongcheon, Korea, were washed, stemmed, and crushed for wine fermentation. Grape must $(5 \mathrm{~kg})$ was fermented by co-culture of non-Saccharomyces yeasts (W. anomalus JK04 and M. pulcherrima S36) and S. cerevisiae W-3 (9:1, v/v) at $20^{\circ} \mathrm{C}$ for 7 days, and $100 \mathrm{mg} / \mathrm{L}$ $\mathrm{K}_{2} \mathrm{~S}_{2} \mathrm{O}_{5}$ was added to prevent bacterial contamination. The control wine was fermented by single-culture of $S$. cerevisiae W-3.

\subsection{Analysis of Wine Characteristics and Viable Cell Counts}

All the wine samples were prepared by centrifugation $(3578 \times g, 10 \mathrm{~min})$ to analyze their fermentation characteristics. Soluble solids were measured with a refractometer and reducing sugar content was analyzed using dinitrosalicylic acid according to AOAC guidelines [31]. The $\mathrm{pH}$ was measured with a pH meter (Mettler-Toledo, Schwerzenbach, Switzerland), and total acidity was determined by titration of filtrates with $0.1 \mathrm{~N} \mathrm{NaOH}$ (expressed as \% tartaric acid). Alcohol content was measured with a hydrometer based on the specific gravity of wine distillates (expressed as $\% v / v$ ) at $15^{\circ} \mathrm{C}$ [31]. The total phenolic compound content was determined by the Folin-Ciocalteau method [32]. The organic acid content was determined by HPLC (Model Prominence, Shimadzu, Kyoto, Japan) using a PL Hi-Plex H column (diam. $7.7 \times 300$ mm; Agilent Technologies, Santa Clara, CA, USA). The column chromatography conditions were as follows: flow rate, $1 \mathrm{~mL} / \mathrm{min}$; temperature, $65^{\circ} \mathrm{C}$; 
mobile phase, $0.005 \mathrm{~mol}$ sulfuric acid. Organic acids were detected with a refractive index detector (RID-10A, Shimadzu).

\subsection{Volatile Aromatic Compounds in Muscat Bailey A Wine}

To confirm the effects of non-Saccharomyces yeasts on wine aroma, the volatile aromatic compounds in MBA wine were quantified using gas chromatography mass spectrometry (7890A GC-MS; Agilent, Santa Clara, CA, USA) equipped with a flame ionization detector (FID). The separation was performed with a DB-WAX column ( $60 \mathrm{~m} \times 250 \mu \mathrm{m} \times 0.25 \mathrm{~mm}$; Waters, Milford, MA, USA), and detected with a triple-axis Agilent 5975C Inert XL MSD detector. Helium was used as a carrier gas with a constant flow rate of $1 \mathrm{~mL} / \mathrm{min}$. The oven of the chromatograph was programmed as follows: initial hold at $40{ }^{\circ} \mathrm{C}$ for $2 \mathrm{~min}$, increased by $2{ }^{\circ} \mathrm{C} / \mathrm{min}$ up to $220^{\circ} \mathrm{C}$, and then increased continuously at $20^{\circ} \mathrm{C} / \mathrm{min}$ up to $240{ }^{\circ} \mathrm{C}$, with a final hold at $240{ }^{\circ} \mathrm{C}$ for $5 \mathrm{~min}$. Volatile aromatic compounds were collected from the wine using a solid-phase microextraction (SPME) fiber (50/30 $\mu \mathrm{m}$ DVB/CAR/PDMS; Supelco, Bellefonte, PA, USA) in headspace (HS) mode with magnetic stirring. Five milliliters of the sample was placed in an HS vial (20 mm, PTFE/silicon septum, magnetic cap), and $1.25 \mathrm{~g}$ of $\mathrm{NaCl}$ was added to increase the volatile aromatic compound concentration in the headspace by increasing the retention of water-soluble components. Prior to extraction, the sample was shaken in a water bath at $35^{\circ} \mathrm{C}$ for $20 \mathrm{~min}$ to achieve equilibrium. The SPME fiber was then spiked into the vial and exposed at $35{ }^{\circ} \mathrm{C}$ for $40 \mathrm{~min}$. The commercial standards for quantification were supplied by Sigma Aldrich (St. Louis, MO, USA). Volatile aromatic compound identification was based on comparison of their gas chromatograph retention times and mass spectra with reference to spectral data from the Wiley9Nist 0.8 library (Wiley9Nist 0.8 library, mass spectral search program, v. 5.0, USA) [33]. The amount of each compound in the wine was calculated using the peak area based on the chemical standards.

\subsection{Sensory Evaluation}

Sensory evaluation was performed using the nine-point hedonic scale. Before the sensory evaluation, each wine was placed in a sample bottle and left undisturbed at room temperature for $1 \mathrm{~h}$ with the lid closed. After flavor evaluation, each wine was poured into wine glasses to evaluate the color, taste, and overall preference. The panel was composed of 20 judges with sensitive taste discrimination from the Department of Food Science and Technology, Kyungpook National University, Korea. Each judge evaluated the wines with at least 3-min intervals between samples, and water was provided to cleanse the palate. Sensory scores were assigned as follows: 9 (like extremely), 5 (neither like or dislike), 1 (dislike extremely).

\subsection{Statistical Analysis}

All experiments were carried out in at least triplicate and the results were analyzed using the Statistical Package for the Social Sciences (SPSS, v. 12.0 for Windows) to obtain means and standard deviations. Significance was determined at $p<0.05$ using Student's $t$-test and one-way analysis of variance, followed by Duncan's multiple range test.

\section{Results and Discussion}

\subsection{Isolation and Identification of Non-Saccharomyces Yeasts Using PCR-RFLP Analysis}

Various non-Saccharomyces yeasts isolated from several food materials were tested for their potential in improving the aroma of wine during fermentation. W. anomalus JK04 and T. delbrueckii JK08 were previously isolated from nuruk, which is used as a source of microflora for rice wine and to improve the organoleptic properties in bread and wine [22,34]. In addition, 36 isolates from MBA grapes, 12 isolates from persimmons, and 36 isolates from Sémillon grapes were classified using PCR-RFLP analysis (Figure S1). Seven, four, and two types of strain were distinguished in Sémillon grapes, persimmons, and MBA grapes, respectively, depending on the fragment patterns digested with 
Hinf I, Hae III, and Hpa I endonucleases (Table S1). The seven isolates showing the highest OD value among each of the species when cultured in sterilized MBA grape juice at $30^{\circ} \mathrm{C}$ for $48 \mathrm{~h}$ were selected for further study and identified as Starmerella bacillaris MR35, Candida quercitrusa P6, Pichia kluyveri P11, Hanseniaspora vineae S7, H. uvarum S8, Candida railenensis S18, and Metschnikowia pulcherrima S36 using amplicons of the ITS I-5.8S-ITS II region in a BLAST search in the NCBI database (www.ncbi.nlm.nih.gov). The ITS I-5.8S-ITS II region DNA sequences of the nine non-Saccharomyces yeasts were submitted to the GenBank database under accession numbers MF574300-MF574308 (Table 1).

Table 1. Strains used in this study.

\begin{tabular}{ccccc}
\hline Species & Strains & Origin & GenBank Accession Number & Reference \\
\hline Saccharomyces cerevisiae & W-3 & - & - & {$[35]$} \\
Wickerhamomyces anomalus & JK04 & Nuruk & MF574300 & {$[22]$} \\
Torulaspora delbrueckii & JK08 & Nuruk & MF574301 & {$[22]$} \\
Starmerella bacillaris & MR35 & Muscat Bailey A(MBA) grape & MF574302 & This study \\
Candida quercitrusa & P6 & Persimmon & MF574303 & This study \\
Pichia kluyveri & P11 & Persimmon & MF574304 & This study \\
Hanseniaspora vineae & S7 & Sémillon & MF574305 & This study \\
Hanseniaspora uvarum & S8 & Sémillon & MF574306 & This study \\
Candida railenensis & S18 & Sémillon & MF574307 & This study \\
Metschnikowia pulcherrima & S36 & Sémillon & MF574308 & This study \\
\hline
\end{tabular}

Several researchers have used PCR-RFLP analysis with different restriction endonucleases to confirm the dynamics of non-Saccharomyces yeasts during spontaneous wine fermentation or at the early stage of winemaking for rapid identification [36-39]. Alternatively, yeast dynamics can be investigated with slightly modified methods, such as simple sequence repeat fingerprinting, tandem repeat-tRNA PCR, or denaturing gradient gel electrophoresis PCR [40-42]. In this study, the results of PCR-RFLP analysis using different endonucleases quickly distinguished between each species with clearly different fragment patterns.

\subsection{Physiological Characteristics of Non-Saccharomyces Yeasts}

The carbon fermentation and assimilation analysis showed that all strains exhibited similar patterns to the reference strains described by Kurtzman's method [29] (Table 2). Among nine non-Saccharomyces yeasts, P. kluyveri P11, H. vineae S7, H. uvarum S8, and M. pulcherrima S36 utilized only glucose as a carbon source for assimilation, which may result in low ethanol contents after fermentation or a slow fermentation rate. Accordingly, many researchers have applied these yeasts in wine fermentation using co-fermentation with $S$. cerevisiae to increase thiol concentration [43], improve the organoleptic quality and reduce the volatile acidity [44], increase flavor diversity [45], and increase foam persistence (especially in sparkling wine) and change aromatic profile [46]. W. anomalus JK04 and T. delbrueckii JK08 showed similar carbon fermentation patterns to the control strain S. cerevisiae W-3, except for galactose (delayed positive) and maltose (negative), respectively. S. bacillaris MR35 could also use sucrose and raffinose as carbon sources for fermentation, whereas C. quercitrusa P6 and C. railenensis S18 could also utilize galactose. W. anomalus JK04, T. delbrueckii JK08, C. quercitrusa P6, C. railenensis S18, and M. pulcherrima S36 were able to use more types of carbon sources for assimilation than S. cerevisiae W-3, whereas S. bacillaris MR35 showed positive results for only glucose, sucrose, and raffinose (matching the positive results in carbon fermentation analysis), with a weak positive result for L-sorbose, and negative results for all other carbon sources. In addition, P. kluyveri P11, H. vineae S7, and H. uvarum S8 also utilized only a few types of carbon source for assimilation. W. anomalus JK04, H. vineae S7, H. uvarum S8, C. railenensis S18, and M. pulcherrima S36 showed positive results for the assimilation of cellobiose, which is a known substrate of $\beta$-glucosidase and is involved in the production of monoterpenes related to the aromatic compounds in wine. Indeed, these strains have been used in investigations for increasing the monoterpene content to improve wine aroma $[5,8]$. 
Table 2. Carbon fermentation and assimilation characteristics of Saccharomyces cerevisiae W-3 and nine non-Saccharomyces yeasts.

\begin{tabular}{|c|c|c|c|c|c|c|c|c|c|c|c|c|c|c|c|c|c|c|c|c|c|}
\hline \multirow{2}{*}{$\begin{array}{l}\text { Carbon } \\
\text { Source }\end{array}$} & \multicolumn{10}{|c|}{ Strains } & \multirow{2}{*}{ Carbon Source } & \multicolumn{10}{|c|}{ Strains } \\
\hline & $\mathrm{W}-3$ & JK04 & JK08 & MR35 & P6 & P11 & S7 & S8 & S18 & S36 & & W-3 & JK04 & JK08 & MR35 & P6 & P11 & S7 & S8 & $\mathrm{S} 18$ & S36 \\
\hline \multicolumn{11}{|c|}{ Fermentation } & D-Xylose & - & + & - & - & + & - & - & - & + & + \\
\hline D-Glucose & + & + & + & + & + & + & + & + & + & + & Erythritol & - & + & - & - & - & - & - & - & - & - \\
\hline D-Galactose & + & d & + & - & + & - & - & - & + & - & Galactitol & - & - & - & - & - & - & - & - & - & - \\
\hline Maltose & + & + & - & - & - & - & - & - & - & - & D-Glucitol & - & + & + & - & + & - & - & - & + & + \\
\hline Sucrose & + & + & + & + & - & - & - & - & - & - & Glycerol & - & + & - & - & + & + & - & - & + & + \\
\hline Lactose & - & - & - & - & - & - & - & - & - & - & myo-Inositol & - & - & - & - & - & - & - & - & - & - \\
\hline Trehalose & - & - & - & - & - & - & - & - & - & - & D-Mannitol & - & + & + & - & + & - & - & - & + & + \\
\hline Raffinose & + & + & + & + & - & - & - & - & - & - & Ribitol & - & - & - & - & + & - & - & - & + & + \\
\hline \multicolumn{11}{|c|}{ Assimilation } & Ethanol & + & + & + & - & + & + & - & - & + & + \\
\hline D-Glucose & + & + & + & + & + & + & + & + & + & + & Methanol & - & - & - & - & - & - & - & - & - & - \\
\hline D-Galactose & + & + & + & - & + & - & - & - & + & + & Citrate & - & - & - & - & + & - & - & - & + & + \\
\hline L-Sorbose & - & - & - & $\mathrm{w}$ & + & - & - & - & + & + & DL-Lactate & - & - & - & - & + & - & - & - & + & - \\
\hline Cellobiose & - & + & - & - & - & - & + & + & + & + & Succinate & - & + & - & - & + & $\mathrm{s}$ & - & - & + & + \\
\hline Lactose & - & - & - & - & - & - & - & - & - & - & D-Gluconate & - & - & - & - & + & $\mathrm{s}$ & - & + & $\mathrm{w}$ & $\mathrm{w}$ \\
\hline Maltose & + & + & - & - & + & - & $\mathrm{w}$ & - & + & + & $\alpha$-Methyl-D-glucoside & - & + & - & - & + & - & - & - & + & + \\
\hline Melibiose & - & - & + & - & - & - & - & - & - & - & Salicin & - & + & - & - & - & + & + & + & + & + \\
\hline Sucrose & + & + & + & + & + & $\mathrm{w}$ & - & - & + & + & $\begin{array}{l}\text { D-Glucosamine } \\
\text { hydrochloride }\end{array}$ & - & - & - & - & - & $\mathrm{s}$ & - & - & - & - \\
\hline Trehalose & + & $\mathrm{w}$ & $\mathrm{s}$ & - & + & - & - & - & + & + & $N$-Acetyl-D-glucosamine & - & - & - & - & + & + & - & - & + & + \\
\hline Melezitose & + & + & $\mathrm{w}$ & - & + & - & - & - & + & + & Hexadecane & - & - & - & - & - & - & - & - & $\mathrm{w}$ & - \\
\hline Raffinose & + & + & + & + & - & - & - & - & - & - & 2-Keto-D-gluconate & + & - & + & - & + & - & - & + & + & + \\
\hline Inulin & - & - & - & - & - & - & - & - & - & - & 5-Keto-D-gluconate & + & + & + & - & + & + & - & - & + & + \\
\hline Starch & - & + & - & - & - & - & - & - & - & - & Saccharate & - & - & - & - & - & - & - & - & - & - \\
\hline D-Arabinose & - & - & - & - & - & - & - & - & $\mathrm{d}$ & - & Arbutin & - & + & - & - & $\mathrm{d}$ & - & + & + & + & + \\
\hline L-Arabinose & - & - & - & - & - & - & - & - & - & - & D-Glucuronate & - & - & - & - & - & - & - & - & - & - \\
\hline D-Ribose & - & - & - & - & - & - & - & - & - & - & Xylitol & - & $\mathrm{w}$ & - & - & + & + & - & - & + & + \\
\hline L-Rhamnose & - & - & - & - & - & - & - & - & - & - & L-Arabinitol & - & - & - & - & - & - & - & - & - & - \\
\hline
\end{tabular}




\subsection{Biochemical Characteristics for Carbon Assimilation of Non-Saccharomyces Yeasts}

The tolerances to several environmental parameters were investigated in the non-Saccharomyces strains to determine their potential in winemaking and aroma improvement (Table 3). Although only minor growth inhibition was detected between YPD broth containing 50\% glucose and 20\% glucose for all strains, there was still sufficiently high cell growth in both conditions, indicating that osmotic stress has a negligible influence on wine fermentation. In contrast, all of the non-Saccharomyces yeasts, except for W. anomalus JK04, showed significantly reduced cell growth in YPD broth containing 8\% ethanol, and W. anomalus JK04 also showed low cell growth in YPD broth containing 12\% ethanol, supporting the presence of non-Saccharomyces yeasts during the initial phase of wine fermentation, thereby exerting a greater influence on the formation of various aromatic compounds $[47,48]$. In the $\mathrm{pH}$ tolerance analysis, Hanseniaspora sp. (S7 and S8) and M. pulcherrima S36 showed weak pH tolerances when cultured in YPD broth adjusted to $\mathrm{pH} 4$, which is similar to the acidic condition of wine. Moreover, W. anomalus JK04, S. bacillaris MR35, C. quercitrusa P6, H. uvarum S8, and C. railenensis S18 showed strong acid tolerances when cultured in YPD broth adjusted to $\mathrm{pH}$ 2. Hanseniaspora spp. (S7 and S8) and $S$. bacillaris MR35 were very sensitive to $\mathrm{SO}_{2}$ stress conditions, indicating that lower $\mathrm{SO}_{2}$ treatment is preferable for wine fermentation by $S$. bacillaris MR35 or Hanseniaspora species. The results of fermentation rate indicated that W. anomalus JK04, T. delbrueckii JK08, S. bacillaris MR35, and H. vineae S7 converted over $80 \%$ of the glucose to $\mathrm{CO}_{2}$, whereas the other non-Saccharomyces strains showed relatively low fermentation rates (Table 3). Because the cultivation times of non-Saccharomyces yeasts were too long to complete fermentation, these non-Saccharomyces yeasts are most likely to affect wine properties during the early phase of fermentation (Figure S2). Although some strains showed good potential for sole use in winemaking because they fermented over $80 \%$ of the glucose available, co-fermentation with $S$. cerevisiae and non-Saccharomyces yeasts is still considered a better approach for producing more favorable wines and avoiding contamination of foreign microorganisms by reducing the fermentation time.

\subsection{Enzymatic Activity and the Effect of Growth Medium on $\beta$-Glucosidase Production}

The enzymes produced by non-Sacharomyces yeasts play an important role in the development of abundant wine aroma and improving the sensory properties of wine [49]. Nineteen types of enzyme activities of non-Saccharomyces yeasts were verified using API ZYM (Figure 1). None of the non-Saccharomyces strains showed lipase, trypsin, $\alpha$-chymotrypsin, $\beta$-galactosidase, $\beta$-glucuronidase, $N$-acetyl- $\beta$-glucosaminidase, $\alpha$-mannosidase, or $\alpha$-fucosidase activities, whereas esterase lipase, leucine arylamidase, valine arylamidase, cystine arylamidase, and naphthol-AS-BI-phosphohydrolase activities were detected in all strains (except for crystine arylamidase in H. uvarum S8). Alkaline phosphatase activity was detected weakly or not at all in all strains, whereas acid phosphatase activity was detected in all strains, although H. vineae S7, H. uvarum S8, and M. pulcherrima S36 exhibited relatively weaker activity compared to that of the other strains, which is in line with the result of the acid tolerance analysis ( $\mathrm{pH} 4$ ) (Table 3). $\alpha$-Glucosidase activity was detected in S. cerevisiae W-3, W. anomalus JK04, C. quersitrusa P6, H. vineae S7, C. railenensis S18, and M. pulcherrima S36, whereas $\alpha$-galactosidase activity was detected only in T. delbrueckii JK08, in accordance with the results of maltose and melibiose assimilation analysis, respectively. Esterase activity, which is involved in the formation of volatile aromatic ester compounds [50], was detected at a similar level or weakly in all non-Saccharomyces yeasts compared to that of the control (S. cerevisiae W-3). $\beta$-Glucosidase activity, which is related to the release of terpenes into wine [51], was detected in W. anomalus JK04, H. vineae S7, H. uvarum S8, C. railenensis S18, and $M$. pulcherrima S36, corresponding to the results of the cellobiose assimilation analysis (Figure 1). The five strains with $\beta$-glucosidase activity were selected for further analysis. 
Table 3. Tolerance to various environmental stressors and fermentation rates of Saccharomyces cerevisiae W-3 and nine non-Saccharomyces yeasts.

\begin{tabular}{|c|c|c|c|c|c|c|c|c|c|}
\hline \multirow[b]{2}{*}{ Strains } & \multicolumn{8}{|c|}{ Environmental Tolerance (OD $600 \mathrm{~nm}$ ) } & \multirow[b]{2}{*}{$\begin{array}{c}\text { Fermentation Rate } \\
(\%)\end{array}$} \\
\hline & $20 \%$ Glucose & $50 \%$ Glucose & $8 \% \mathrm{EtOH}$ & $12 \% \mathrm{EtOH}$ & pH 4 & pH 2 & $\begin{array}{c}200 \mathrm{mg} / \mathrm{L} \\
\mathrm{K}_{2} \mathrm{~S}_{5} \mathrm{O}_{2}\end{array}$ & $\begin{array}{c}500 \mathrm{mg} / \mathrm{L} \\
\mathrm{K}_{2} \mathrm{~S}_{5} \mathrm{O}_{2}\end{array}$ & \\
\hline W-3 & $42.63 \pm 1.24$ & $32.70 \pm 2.28$ & $12.21 \pm 1.64$ & $3.00 \pm 0.53$ & $33.60 \pm 1.13$ & $1.16 \pm 0.05$ & $18.68 \pm 2.11$ & $20.78 \pm 4.63$ & $90.47 \pm 1.30$ \\
\hline JK04 & $28.13 \pm 1.66$ & $30.08 \pm 1.52$ & $15.20 \pm 2.03$ & $1.78 \pm 0.66$ & $23.63 \pm 2.46$ & $7.15 \pm 0.47$ & $27.33 \pm 6.47$ & $24.13 \pm 1.60$ & $87.40 \pm 1.58$ \\
\hline JK08 & $43.03 \pm 2.51$ & $33.73 \pm 3.39$ & $3.51 \pm 0.46$ & $1.22 \pm 0.07$ & $35.70 \pm 2.85$ & $1.17 \pm 0.07$ & $20.23 \pm 3.57$ & $16.98 \pm 1.66$ & $86.89 \pm 0.36$ \\
\hline MR35 & $38.80 \pm 1.91$ & $25.93 \pm 2.81$ & $2.30 \pm 0.12$ & $1.03 \pm 0.42$ & $25.48 \pm 2.18$ & $10.83 \pm 1.00$ & $15.69 \pm 1.52$ & $14.00 \pm 1.93$ & $84.12 \pm 2.21$ \\
\hline P6 & $24.30 \pm 1.28$ & $18.45 \pm 1.49$ & $2.14 \pm 0.24$ & $0.70 \pm 0.03$ & $30.73 \pm 2.16$ & $9.60 \pm 0.79$ & $30.83 \pm 3.15$ & $28.20 \pm 2.21$ & $53.32 \pm 0.84$ \\
\hline P11 & $28.85 \pm 2.64$ & $26.13 \pm 2.72$ & $1.43 \pm 0.07$ & $0.41 \pm 0.01$ & $24.60 \pm 1.14$ & $1.41 \pm 0.21$ & $20.38 \pm 2.32$ & $21.80 \pm 3.18$ & $37.35 \pm 2.12$ \\
\hline S7 & $31.75 \pm 2.26$ & $25.13 \pm 1.39$ & $1.25 \pm 0.23$ & $0.41 \pm 0.04$ & $16.03 \pm 1.17$ & $1.39 \pm 0.08$ & $16.75 \pm 1.78$ & $12.43 \pm 1.44$ & $87.50 \pm 0.95$ \\
\hline S8 & $28.40 \pm 1.41$ & $23.35 \pm 3.75$ & $1.12 \pm 0.44$ & $0.49 \pm 0.02$ & $10.21 \pm 1.85$ & $4.35 \pm 0.92$ & $12.12 \pm 1.53$ & $11.42 \pm 1.25$ & $41.55 \pm 1.20$ \\
\hline S18 & $25.68 \pm 1.45$ & $23.73 \pm 2.65$ & $1.15 \pm 0.48$ & $0.37 \pm 0.03$ & $25.93 \pm 3.04$ & $5.73 \pm 0.25$ & $34.18 \pm 4.77$ & $29.73 \pm 3.53$ & $49.74 \pm 2.54$ \\
\hline S36 & $29.10 \pm 3.32$ & $27.65 \pm 1.21$ & $0.78 \pm 0.03$ & $0.38 \pm 0.02$ & $8.05 \pm 0.38$ & $1.79 \pm 0.24$ & $26.35 \pm 1.48$ & $30.20 \pm 4.99$ & $44.52 \pm 1.31$ \\
\hline
\end{tabular}




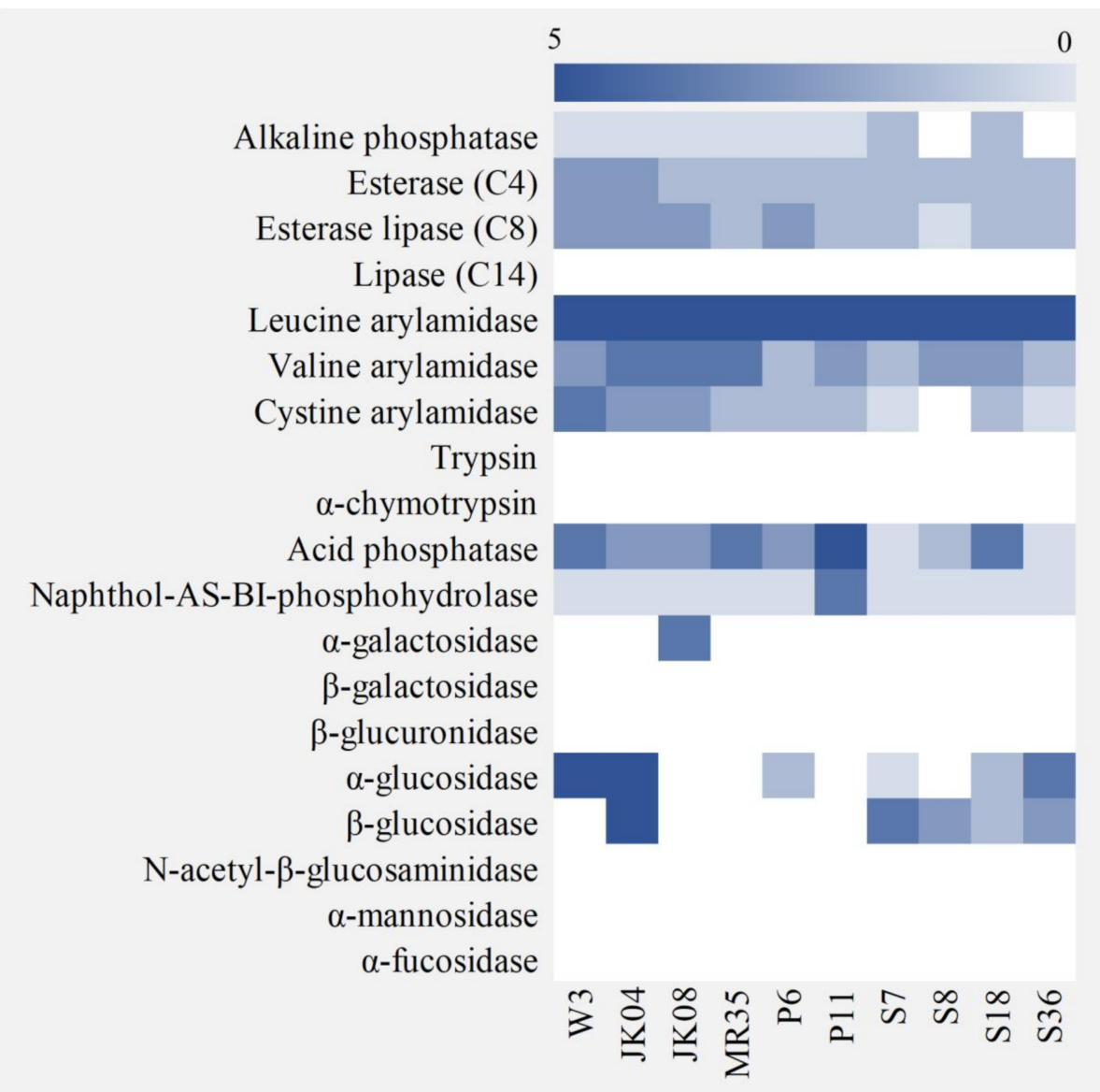

Figure 1. Heatmap of enzymatic activities of Saccharomyces cerevisiae W-3 and non-Saccharomyces yeasts isolated from various food materials. All activities were determined using an API ZYM kit. W-3, Saccharomyces cerevisiae W-3; JK04, Wickerhamomyces anomalus JK04; JK08, Torulaspora delbrueckii JK08; MR35, Starmerella bacillaris MR35; P6, Candida quercitrusa P6; P11, Pichia kluyveri P11; S7, Hanseniaspora vineae S7; S8, H. uvarum S8; S18, Candida railenensis S18; S36, Metschnikowia pulcherrima S36.

The $\beta$-glucosidase activity was quantified in five non-Saccharomyces strains grown on media with different carbon sources: YPD, YPDC, and YPC (Figure 2). The $\beta$-glucosidase production of $W$. anomalus JK04 and M. pulcherrima S36 was higher than that of the other strains, regardless of the growth medium composition. The $\beta$-glucosidase activities of $W$. anomalus JK04 and $M$. pulcherrima S36 were 1.72, 2.03, and $2.55 \mathrm{U} \mathrm{mL}^{-1} \mathrm{~min}^{-1}$ (JK04) and 2.06, 2.76, and $2.55 \mathrm{U} \mathrm{mL}^{-1} \mathrm{~min}^{-1}$ (S36) when cultured in YPD, YPDC, and YPC, respectively. Although $H$. vineae $\mathrm{S} 7$ also showed increased $\beta$-glucosidase activity in all conditions, it was still relatively weaker compared to that of $W$. anomalus JK04 and M. pulcherrima S36 (1.03-1.64 $\mathrm{U} \mathrm{mL}^{-1} \mathrm{~min}^{-1}$ ). In the case of $C$. railenensis $\mathrm{S} 18$, significantly high $\beta$-glucosidase activities were detected when it was cultured in YPD and YPDC $\left(2.00\right.$ and $1.75 \mathrm{U} \mathrm{mL}^{-1} \mathrm{~min}^{-1}$, respectively), whereas limited activity was detected when it was cultured in YPC. H. uvarum S8 showed very weak $\beta$-glucosidase activities in all conditions, which differed to the result of the API ZYM kit (Figure 1). Among those five strains, W. anomalus JK04 and M. pulcherrima S36 showed relatively high $\beta$-glucosidase activities in all conditions. $\beta$-Glucosidase is a common enzyme that exists in nature, but $\beta$-glucosidases produced by $S$. cerevisiae and grapes are typically inactivated or inhibited under wine production conditions, such as $\mathrm{pH} 3-4$ or high sugar levels $[5,52,53]$. Thus, several researchers have studied non-Saccharomyces yeasts, including H. uvarum, W. anomalus, P. kudriavzevii, M. pulcherrima, and Issatchenkia terricola, as $\beta$-glucosidase producers for improving wine aroma with high $\beta$-glucosidase activities and without glucose and low-pH repression $[5,10,52,54]$. In the present study, W. anomalus 
JK04 and M. pulcherrima S36, which showed the highest $\beta$-glucosidase activities, were selected for further investigation of volatile terpene compounds.
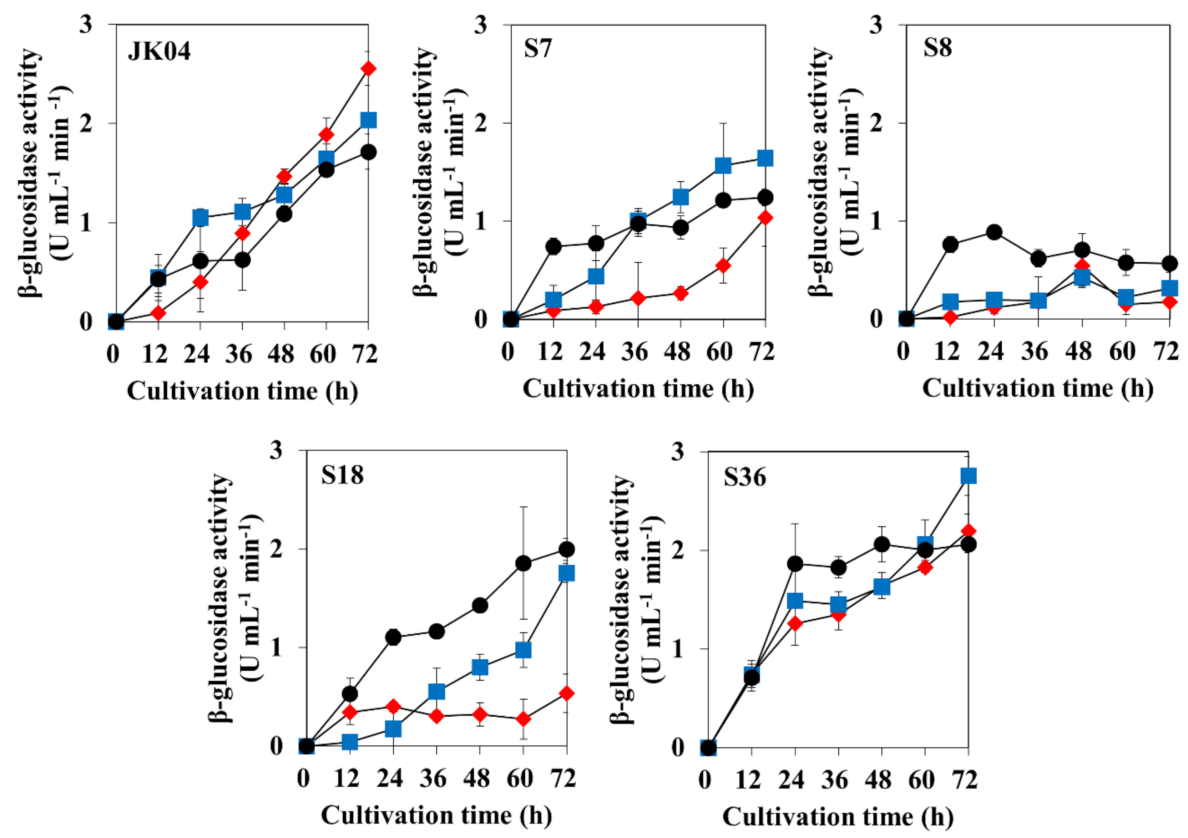

Figure 2. Effect of growth medium on $\beta$-glucosidase activities of five non-Saccharomyces yeasts when cultured on yeast peptone dextrose (YPD) (black circles), yeast peptone dextrose cellobiose (YPDC) (blue squares), and yeast peptone cellobiose (YPC) (red diamonds). JK04, Wickerhamomyces anomalus JK04; S7, Hanseniaspora vineae S7; S8, H. uvarum S8; S18, Candida railenensis S18; S36, Metschnikowia pulcherrima S36. YPD and YPC contain $2 \%$ of glucose and cellobiose, respectively. YPDC contains 1\% of glucose and $1 \%$ of cellobiose.

3.5. Effect of $\beta$-Glucosidase-Producing Non-Saccharomyces Yeasts on Fermentation Characteristics and Volatile Aromatic Profiling of MBA Wine

The fermentation characteristics of MBA wine co-fermented with W. anomalus JK04 (JK04 wine) or M. pulcherrima S36 (S36 wine), which showed the highest $\beta$-glucosidase producing activities, and $S$. cerevisiae W-3 were investigated (Figure 3 and Table 4 ). The viable cell count of W. anomalus JK04 was maintained at $>\log 6 \mathrm{CFU} / \mathrm{mL}$ until fermentation was complete, whereas the viable cell count of $M$. pulcherrima S36 dramatically decreased after the third day of fermentation and no viable cells were detected when fermentation was completed. The alcohol content of the S36 wine was $1 \%$ lower than that of the other MBA wines, probably due to the lower fermentation rate of M. pulcherrima S36 compared to that of S. cerevisiae W-3 and W. anomalus JK04 (Table 3). The pH, reducing sugars, and total phenolic compound contents were not significantly different between the wines, whereas the total acidities of the co-fermented wines were slightly increased. The results of the organic acid analysis showed that the acetic acid content of the co-fermented wines was slightly increased, whereas other compounds were not significantly different. In the volatile ester compound analysis, a total of 13 kinds of volatile ester compounds were detected. The JK04 wine showed higher ethyl acetate and isobutyl acetate contents compared to the control wine, and the S36 wine had increased isobutyl acetate, isobutyl octanoate, ethyl decanoate, ethyl octanoate, isoamyl octanoate, and methyl salicylate contents compared to the other wines, whereas the highest amounts of n-hexyl acetate and 2-phenylethyl acetate were detected in the control wine. Of note, all the wines had significantly higher isoamyl acetate and 2-phenylethyl acetate contents compared with those generally reported in other studies. Regarding volatile terpene compounds, only three kinds of volatile terpene compounds were detected. The linalool, citronellol, and geraniol contents of the JK04 and S36 wines were significantly increased to $13.8-46.9 \%$ and $16.5-27.2 \%$, respectively, which were higher than those of the control wine. 
In the sensory evaluation, the co-fermented wines received higher scores for flavor, taste, and overall preference than the control wine.
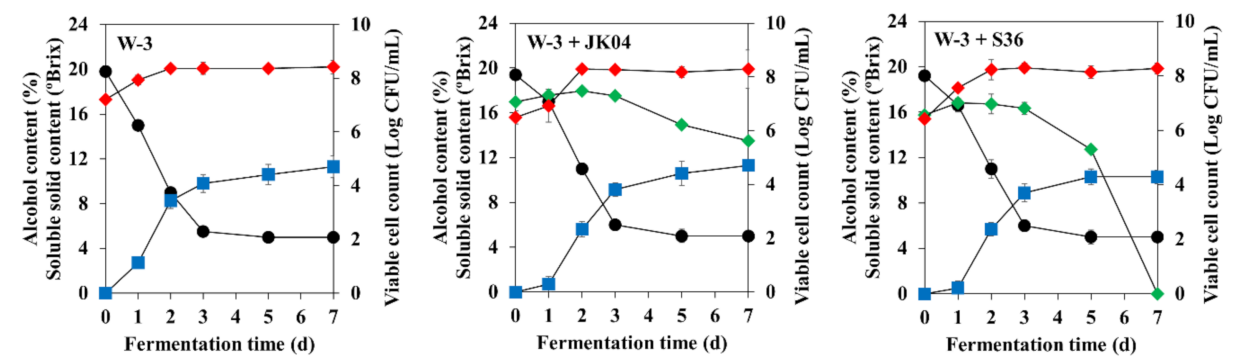

Figure 3. Soluble solids (black circles), alcohol contents (blue squares) and viable cell counts (diamonds) of Muscat Bailey A wine fermented by single culture of Saccharomyces cerevisiae W-3 (W-3), co-culture of S. cerevisiae W-3 and Wickerhamomyces anomalus JK04 (W-3 + JK04), and co-culture of S. cerevisiae W-3 and Metschnikowia pulcherrima S36 (W-3 + S36). Red and green symbols indicate viable cell counts of S. cerevisiae W-3 and non-Saccharomyces yeasts, respectively.

Gonzalez et al. (2013) suggested that using Crabtree-negative non-Saccharomyces yeasts (M. pulcherrmia or W. anomalus) with S. cerevisiae could result in low ethanol contents in final wines [55]. M. pulcherrima S36 could be also considered as a potential wine starter for producing low-alcohol wine. In contrast with $M$. pulcherrima S36, W. anomalus JK04 produced a similar ethanol content to the control wine, but this strain could survive under the high ethanol concentration due to its high ethanol tolerance (Table 3), indicating that W. anomalus JK04 can affect the wine quality across the fermentation process. Similarly, $\beta$-glucosidase from P. anomala MDD24 has also been reported to be very efficient at releasing aromatic compounds during the final phase of wine fermentation due to its high ethanol tolerance [8,54]. While W. anomalus and M. pulcherrima have been known to produce ethyl acetate and fruity esters (especially ethyl octanoate) during fermentation, respectively [11,56], several researchers have also paid attention to applying the $\beta$-glucosidase activities of these strains to improve the volatile terpene compounds in wine $[7,8,10,51,54,57]$. The formation of volatile aromatic compounds, including monoterpenes, is influenced by many factors, such as grape cultivars, geological differences, soil, climate, water, nitrogen fertilization, and harvest time [58,59]. Although only three kinds of volatile terpene compounds, i.e., linalool, citronellol, and geraniol, were detected in this study, the increase of these compounds levels due to W. anomalus JK04 and M. pulcherrima S36 resulted in a significant influence on the odor perception of MBA wine because of the compounds' very low odor thresholds $(0.025,0.1$, and $0.02 \mathrm{mg} / \mathrm{L}$, respectively) [60]. Moreover, all the wines had extraordinarily higher amount of some volatile ester compounds such as isoamyl acetate and 2-phenylethyl acetate than that generally reported [61]. Given our previous studies that used single or co-fermentation with S. cerevisiae W-3 and non-Saccharomyces yeasts, production of excessive isoamyl acetate and 2-phenylethyl acetate is a distinctive trait of S. cerevisiae W-3 [2,62]. Some non-Saccharomyces yeasts, including M. pulcherrima, have been reported to improve wine color owing to their ability to adsorb grape anthocyanins in their cell walls during fermentation [63], indicating that the S36 wine receives a higher color score than other wines. A relatively low ethanol content of the S36 wine also affects the taste of MBA wine. 
Table 4. Physicochemical properties and sensory scores of MBA wine fermented with co-cultures of S. cerevisiae W-3 (W-3) and non-Saccharomyces yeasts.

\begin{tabular}{|c|c|c|c|}
\hline \multirow{2}{*}{ Property } & \multicolumn{3}{|c|}{ Strains } \\
\hline & W-3 & W-3 + JK04 & $\mathrm{W}-3+\mathrm{S} 36$ \\
\hline Alcohol $(\%, v / v)$ & $11.3 \pm 0.1 \mathrm{a}$ & $11.3 \pm 0.1 \mathrm{a}$ & $10.3 \pm 0.1 b$ \\
\hline Soluble solid ( ${ }^{\circ}$ Brix) & $5.0 \pm 0.1 \mathrm{a}$ & $5.0 \pm 0.0 \mathrm{a}$ & $5.0 \pm 0.1 \mathrm{a}$ \\
\hline $\mathrm{pH}$ & $3.73 \pm 0.02 a$ & $3.78 \pm 0.02 \mathrm{a}$ & $3.77 \pm 0.02 \mathrm{a}$ \\
\hline Total acidity (\%) & $0.47 \pm 0.00 \mathrm{~b}$ & $0.55 \pm 0.01 \mathrm{a}$ & $0.57 \pm 0.03 a$ \\
\hline Reducing sugar $(\%)$ & $0.12 \pm 0.01 \mathrm{a}$ & $0.12 \pm 0.01 \mathrm{a}$ & $0.12 \pm 0.01 \mathrm{a}$ \\
\hline Total phenolic compounds (\%) & $0.14 \pm 0.01 \mathrm{a}$ & $0.13 \pm 0.01 \mathrm{a}$ & $0.13 \pm 0.01 \mathrm{a}$ \\
\hline \multicolumn{4}{|c|}{ Organic acids $(\mathrm{mg} / \mathrm{mL})$} \\
\hline Citric acid & $1.07 \pm 0.11 \mathrm{a}$ & $1.14 \pm 0.13 a$ & $1.09 \pm 0.10 \mathrm{a}$ \\
\hline Tartaric acid & $1.58 \pm 0.10 \mathrm{a}$ & $1.56 \pm 0.16 a$ & $1.72 \pm 0.13 a$ \\
\hline Malic acid & $4.60 \pm 0.26 a$ & $4.97 \pm 0.32 \mathrm{a}$ & $4.82 \pm 0.24 \mathrm{a}$ \\
\hline Succinic acid & $1.67 \pm 0.07 a$ & $1.55 \pm 0.05 a$ & $1.62 \pm 0.09 a$ \\
\hline Acetic acid & $0.15 \pm 0.01 b$ & $0.26 \pm 0.03 a$ & $0.21 \pm 0.02 \mathrm{a}$ \\
\hline \multicolumn{4}{|c|}{ Volatile ester compounds (mg/L) } \\
\hline Ethyl acetate & $141.43 \pm 12.38 b$ & $261.12 \pm 23.05 a$ & $151.05 \pm 19.67 \mathrm{~b}$ \\
\hline Isobutyl acetate & $8.84 \pm 0.95 b$ & $11.00 \pm 0.68 \mathrm{a}$ & $12.68 \pm 1.04 \mathrm{a}$ \\
\hline Isoamyl acetate & $545.91 \pm 41.94 \mathrm{a}$ & $493.13 \pm 36.86 a$ & $548.54 \pm 46.25 a$ \\
\hline Ethyl hexanoate & $153.47 \pm 10.12 b$ & $131.47 \pm 12.31 b$ & $182.65 \pm 16.00 \mathrm{a}$ \\
\hline n-Hexyl acetate & $7.64 \pm 0.35 a$ & $3.64 \pm 0.21 \mathrm{c}$ & $5.31 \pm 0.38 b$ \\
\hline Ethyl heptanoate & $1.20 \pm 0.08 \mathrm{a}$ & $1.20 \pm 0.10 \mathrm{a}$ & $1.41 \pm 0.13 \mathrm{a}$ \\
\hline Ethyl octanoate & $426.41 \pm 35.31 b$ & $430.52 \pm 38.14 b$ & $513.40 \pm 21.06 a$ \\
\hline Isobutyl octanoate & $1.49 \pm 0.11 b$ & $1.68 \pm 0.13 b$ & $2.28 \pm 0.20 \mathrm{a}$ \\
\hline Ethyl decanoate & $427.18 \pm 31.68 b$ & $469.09 \pm 29.57 \mathrm{ab}$ & $534.14 \pm 39.63 a$ \\
\hline Isoamyl octanoate & $13.50 \pm 1.65 b$ & $12.63 \pm 1.21 b$ & $16.53 \pm 1.34 \mathrm{a}$ \\
\hline Methyl salicylate & $31.60 \pm 2.15 b$ & $32.54 \pm 3.08 b$ & $39.06 \pm 3.36 \mathrm{a}$ \\
\hline 2-Phenylethyl acetate & $87.26 \pm 6.53 a$ & $36.13 \pm 2.62 \mathrm{c}$ & $62.22 \pm 4.49 b$ \\
\hline Ethyl dodecanoate & $162.81 \pm 12.36 a$ & $143.79 \pm 10.30 \mathrm{a}$ & $142.20 \pm 11.27 \mathrm{a}$ \\
\hline \multicolumn{4}{|c|}{ Volatile terpene compounds (mg/L)/*Increase level (\%) } \\
\hline Linalool & $0.81 \pm 0.07 \mathrm{c}$ & $1.19 \pm 0.06 \mathrm{a} / 46.9 \%$ & $1.03 \pm 0.08 b / 27.2 \%$ \\
\hline Citronellol & $5.60 \pm 0.25 b$ & $6.37 \pm 0.30 \mathrm{a} / 13.8 \%$ & $6.77 \pm 0.28 \mathrm{a} / 20.9 \%$ \\
\hline Geraniol & $2.00 \pm 0.13 b$ & $2.38 \pm 0.11 \mathrm{a} / 19.0 \%$ & $2.33 \pm 0.13 a / 16.5 \%$ \\
\hline \multicolumn{4}{|c|}{ Sensory score } \\
\hline Color & $5.80 \pm 1.82 \mathrm{a}$ & $5.85 \pm 1.95 a$ & $6.15 \pm 1.84 a$ \\
\hline Flavor & $5.20 \pm 1.89 a$ & $5.60 \pm 1.79 a$ & $5.45 \pm 2.01 \mathrm{a}$ \\
\hline Taste & $4.15 \pm 1.58 \mathrm{a}$ & $4.50 \pm 1.66 a$ & $4.65 \pm 1.38 \mathrm{a}$ \\
\hline Overall preference & $5.65 \pm 1.66 a$ & $6.30 \pm 1.62 a$ & $6.20 \pm 1.63 a$ \\
\hline
\end{tabular}

${ }^{*}$ a-c Different letters within the same row indicate a statistically significant difference $(p<0.05) .{ }^{*}$ Increase in the levels of volatile terpene compounds in co-fermented wines were calculated by comparing with those of the control wine.

\section{Conclusions}

In this study, $\beta$-glucosidase-producing non-Saccharomyces yeasts were investigated to improve Korean MBA wine quality by increasing volatile terpene compounds. A number of non-Saccharomyces yeasts were isolated from various food materials and their physiological, biochemical, and enzymatic properties were investigated. A total of five species of non-Saccharomyces yeasts were confirmed to have $\beta$-glucosidase activities. Among these strains, W. anomalus JK04 and M. pulcherrima S36 had the highest $\beta$-glucosidase activities in all media conditions with different carbon sources. The MBA wines co-fermented with these two non-Saccharomyces yeasts and S. cerevisiae W-3 had significantly increased linalool, citronellol, and geraniol contents. In a sensory evaluation, the flavor, taste, and overall preference scores of these two co-fermented wines were higher than those of the control wine. 
In conclusion, W. anomalus JK04 and M. pulcherrima S36 can contribute to the improved quality of Korean MBA wine.

Supplementary Materials: The following are available online at http:/www.mdpi.com/2076-2607/8/10/1552/s1, Figure S1: PCR-RFLP analysis of amplified ITS I-5.8S-ITS II region of 84 isolates from Sémillon grape (S), persimmon (P), and Muscat Bailey A grape (MR), Figure S2: Fermentation rates of nine non-Saccharomyces yeasts and the control strain Saccharomyces cerevisiae W-3, Table S1: Diversity of yeasts isolated from various food materials such as Sémillon grape (S), persimmon (P) and Muscat Bailey A grape (MR).

Author Contributions: Conceptualization, S.-B.L. and H.-D.P.; methodology, S.-B.L.; software, S.-B.L.; validation, S.-B.L. and H.-D.P.; formal analysis, S.-B.L.; investigation, S.-B.L.; resources, S.-B.L.; data curation, S.-B.L.; writing —original draft preparation, S.-B.L.; writing—review and editing, S.-B.L. and H.-D.P.; visualization, S.-B.L.; supervision, H.-D.P.; project administration, H.-D.P.; funding acquisition, H.-D.P. All authors have read and agreed to the published version of the manuscript.

Funding: This research was funded by the National Research Foundation of Korea, Republic of Korea, grant number NRF-2017R1D1A3B03033451.

Conflicts of Interest: The authors declare no conflict of interest.

\section{References}

1. Stanley, D.; Bandara, A.; Fraser, S.; Chambers, P.J; Stanley, G.A. The ethanol stress response and ethanol tolerance of Saccharomyces cerevisiae. J. Appl. Microbiol. 2010, 109, 13-24. [CrossRef] [PubMed]

2. Lee, S.B.; Banda, C.; Park, H.D. Effect of inoculation strategy of non-Saccharomyces yeasts on fermentation characteristics and volatile higher alcohols and esters in Campbell Early wines. Aust. J. Grape Wine Res. 2019, 25, 384-395. [CrossRef]

3. Rojas, V.; Gil, J.V.; Piñaga, F.; Manzanares, P. Studies on acetate ester production by non-Saccharomyces wine yeasts. Int. J. Food Microbiol. 2001, 70, 283-289. [CrossRef]

4. Swiegers, J.H.; Bartowsky, E.J.; Henschke, P.A.; Pretorius, I.S. Yeast and bacterial modulation of wine aroma and flavour. Aust. J. Grape Wine Res. 2005, 11, 139-173. [CrossRef]

5. Hu, K.; Tao, Y.S.; Zhu, X.L.; Peng, C.T.; Ullah, N. Potential of glycosidase from non-Saccharomyces isolates for enhancement of wine aroma. J. Food Sci. 2016, 81, M935-M943. [CrossRef]

6. Rojas, V.; Gil, J.V.; Piñaga, F.; Manzanares, P. Acetate ester formation in wine by mixed cultures in laboratory fermentation. Int. J. Food Microbiol. 2003, 86, 181-188. [CrossRef]

7. Spagna, G.; Barbagallo, R.N.; Palmeri, R.; Restuccia, C.; Giudici, P. Properties of endogenous $\beta$-glucosidases of a Pichia anomala strain isolated from Sicilian musts and wines. Enzyme Microb. Technol. 2002, 31, 1036-1041. [CrossRef]

8. Swangkeaw, J.; Vichitphan, S.; Butzke, C.E.; Vichitphan, K. Characterization of $\beta$-glucosidases from Hanseniaspora sp. and Pichia anomala with potentially aroma-enhancing capabilities in juice and wine. World J. Microbiol. Biotechnol. 2011, 27, 423-430. [CrossRef]

9. Kuo, H.P.; Wan, R.; Huang, C.Y.; Lai, J.T.; Lo, Y.C.; Huang, S.T. Characterization of an extracellular $\beta$-glucosidase from Dekkera bruxellensis for resveratrol production. J. Food Drug Anal. 2018, 26, 163-171. [CrossRef]

10. Zhang, W.; Zhuo, X.; Hu, L.; Zhang, X. Effects of crude $\beta$-glucosidases from Issatchenkia terricola, Pichia kudriavzevii, Metschnikowia pulcherrima on the flavor complexity and characteristics of wines. Microorganisms 2020, 8, 953. [CrossRef]

11. Benito, A.; Calderón, F.; Benito, S. The influence of non-Saccharomyces species on wine fermentation quality parameters. Fermentation 2019, 5, 54. [CrossRef]

12. Qin, Y.; Park, H.D. Overexpressed acetohydroxyacid reductoisomerase (ILV5) gene in Saccharomyces cerevisiae reduces diacetyl contents in Korean Campbell Early and Muscat Bailey A grape wines. J. Korean Soc. Appl. Biol. Chem. 2012, 55, 799-801. [CrossRef]

13. Lee, S.B.; Choi, W.S.; Jo, H.J.; Yeo, S.H.; Park, H.D. Optimization of air-blast drying process for manufacturing Saccharomyces cerevisiae and non-Saccharomyces yeast as industrial wine starters. AMB Express 2016, 6, 105. [CrossRef] [PubMed]

14. Hwang, S.W.; Park, H.D. Characteristics of red wine fermentation of freeze-concentrated Campbell Early grape juice using various wine yeasts. Korean J. Food Preserv. 2009, 16, 977-984. 
15. Lee, J.Y.; Chae, S.K. Studies on the changes in the extraction of phenolics and color characteristics by the enzyme treatment of red grape (Muscat Bailey A) wine during fermentation. Korean J. Food Nutr. 2010, 23, 323-331.

16. Maicas, S.; Mateo, J.J. Hydrolysis of terpenyl glycosides in grape juice and other fruit juices: A review. Appl. Microbiol. Biotechnol. 2005, 67, 322-335. [CrossRef]

17. Mateo, J.J.; Jiménez, M. Monoterpenes in grape juice and wines. J. Chromatogr. A 2000, 881, 557-567. [CrossRef]

18. Rapp, A.; Mandery, H. Wine aroma. Experientia 1986, 42, 873-884. [CrossRef]

19. Choi, K.T.; Lee, S.B.; Jeon, S.H.; Lee, W.C.; Choi, J.S.; Park, H.D. Quality characteristics and antioxidant activities of Muscat Bailey A wines mixed with different types of aronia. Korean J. Food Preserv. 2020, 217, 74-84. [CrossRef]

20. Hwang, S.W.; Park, H.D. Properties of red wine fermented using freeze-concentrated Muscat Bailey A grape juice. Korean J. Food Preserv. 2010, 17, 807-813.

21. Kim, M.S.; Park, H.D. Reduction in the contents of acetaldehyde, methanol and fusel alcohols in the Muscat Bailey A wine fermented by Korean indigenous sugar-tolerant yeasts Saccharomyces cerevisiae S13 and D8. Korean J. Food Preserv. 2014, 21, 851-858. [CrossRef]

22. Wahyono, A.; Lee, S.B.; Kang, W.W.; Park, H.D. Improving bread quality using co-cultures of Saccharomyces cerevisiae, Torulaspora delbrueckii JK08, and Pichia anomala JK04. Ital. J. Food Sci. 2016, 28, 298-313.

23. Kaiser, C.; Michaelis, S.; Mitchell, A. Methods in Yeast Genetics; Cold Spring Harbor Laboratory Press: New York, NY, USA, 1994.

24. Philippsen, P.; Stotz, A.; Scherf, C. DNA of Saccharomyces cerevisiae. Meth. Enzymol. 1991, 194, 169-182. [PubMed]

25. Montrocher, R.; Verner, M.C.; Briolay, J.; Gautier, C.; Marmeisse, R. Phylogenetic analysis of the Saccharomyces cerevisiae group based on polymorphisms of rDNA spacer sequences. Int. J. Syst. Evol. Microbiol. 1998, 48, 295-303. [CrossRef] [PubMed]

26. Sambrook, J.; Russel, D.W. Molecular Cloning, 3rd ed.; A Laboratory Manual; Cold Spring Harbor Laboratory Press: New York, NY, USA, 2001.

27. Altschul, S.F.; Madden, T.L.; Schäffer, A.A.; Zhang, J.; Zhang, Z.; Miller, W.; Lipman, D.J. Gapped BLAST and PSI-BLAST: A new generation of protein database search programs. Nucleic Acids Res. 1997, 25, 3389-3402. [CrossRef] [PubMed]

28. Yeo, S.; Lee, S.; Park, H.; Shin, H.; Holzapfel, W.; Huh, C.S. Development of putative probiotics as feed additives: Validation in a porcine-specific gastrointestinal tract model. Appl. Microbiol. Biotechnol. 2016, 100, 10043-10054. [CrossRef] [PubMed]

29. Kurtzman, C.P.; Fell, J.W. The Yeasts, a Taxonomic Study, 4th ed.; Elsevier Science Publishers: Amsterdam, The Netherlands, 1998; pp. 89-94.

30. Jung, Y.J.; Park, H.D. Antisense-mediated inhibition of acid trehalose (ATH1) gene expression promotes ethanol fermentation and tolerance in Saccharomyces cerevisiae. Biotechnol. Lett. 2005, 27, 1855-1859. [CrossRef]

31. Cunniff, P.A. (Ed.) Official Methods of Analysis of AOAC International, 16th ed.; AOAC International: Arlington, VA, USA, 1995; pp. 28.1-28.16.

32. Singleton, V.L.; Rossi, J.A. Colorimetry of total phenolics with phosphomolybdic-phosphotungstic acid reagents. Am. J. Enol. Vitic. 1965, 16, 144-158.

33. Lee, S.B.; Kim, D.H.; Park, H.D. Effects of protectant and rehydration conditions on the survival rate and malolactic fermentation efficiency of freeze-dried Lactobacillus plantarum JH287. Appl. Microbiol. Biotechnol. 2016, 100, 7853-7863. [CrossRef]

34. Jeong, H.S.; Lee, S.B.; Yeo, S.B.; Kim, D.H.; Choi, J.S.; Kim, D.H.; Yeo, S.H.; Park, H.D. Blending effect of Campbell Early and aronia wines fermented by the mixed culture of Pichia anomala JK04 and Saccharomyces cerevisiae Fermivin. Korean J. Food Preserv. 2017, 24, 472-482. [CrossRef]

35. Kim, D.H.; Hong, Y.A.; Park, H.D. Co-fermentation of grape must by Issatchenckia orientalis and Saccharomyces cerevisiae reduces the malic acid content in wine. Biotechnol. Lett. 2008, 30, 1633-1638. [CrossRef] [PubMed] 
36. Guillamón, J.M.; Sabaté, J.; Barrio, E.; Cano, J.; Querol, A. Rapid identification of wine yeast species based on RFLP analysis of the ribosomal internal transcribed spacer (ITS) region. Arch. Microbiol. 1998, 169, 387-392. [CrossRef] [PubMed]

37. Esteve-Zarzoso, B.; Peris-Torán, M.J.; Ramón, D.; Querol, A. Molecular characterization of Hanseniaspora species. Antonie van Leeuwenhoek 2001, 80, 85-92. [CrossRef] [PubMed]

38. Zott, K.; Miot-Sertier, C.; Claisse, O.; Lonvaud-Funel, A.; Masneuf-Pomarede, I. Dynamics and diversity of non-Saccharomyces yeasts during the early stages in winemaking. Int. J. Food Microbiol. 2008, 125, 197-203. [CrossRef] [PubMed]

39. Tofalo, R.; Schirone, M.; Telera, G.C.; Manetta, A.C.; Corsetti, A.; Suzzi, G. Influence of organic viticulture on non-Saccharomyces wine yeast populations. Ann. Microbiol. 2011, 61, 57-66. [CrossRef]

40. Zietkiewicz, E.; Rafalski, A.; Labuda, D. Genome fingerprinting by simple sequence repeat (SSR)-anchored polymerase chain reaction amplification. Genomics 1994, 20, 176-183. [CrossRef] [PubMed]

41. Barquet, M.; Martín, V.; Medina, K.; Pérez, G.; Carrau, F.; Gaggero, C. Tandem repeat-tRNA (TRtRNA) PCR method for the molecular typing of non-Saccharomyces subspecies. Appl. Microbiol. Biotechnol. 2012, 93, 807-814. [CrossRef]

42. Wang, C.; Garcia-Fernández, D.; Mas, A.; Esteve-Zarzoso, B. Fungal diversity in grape must and wine fermentation assessed by massive sequencing, quantitative PCR and DGGE. Front. Microbiol. 2015, 6, 1156. [CrossRef]

43. Anfang, N.; Brajkovich, M.; Goddard, M.R. Co-fermentation with Pichia kluyveri increases varietal thiol concentrations in Sauvignon Blanc. Aust. J. Grape Wine Res. 2009, 15, 1-8. [CrossRef]

44. Hong, Y.A.; Park, H.D. Role of non-Saccharomyces yeasts in Korean wines produced from Campbell Early grapes: Potential use of Hanseniaspora uvarum as a starter culture. Food Microbiol. 2013, 34, 207-214. [CrossRef]

45. Medina, K.; Boido, E.; Fariña, L.; Gioia, O.; Gomez, M.E.; Barquet, M.; Gaggero, C.; Dellacassa, E.; Carrau, F. Increased flavour diversity of Chardonnay wines by spontaneous fermentation and co-fermentation with Hanseniaspora vineae. Food Chem. 2013, 141, 2513-2521. [CrossRef] [PubMed]

46. González-Royo, E.; Pascual, O.; Kontoudakis, N.; Esteruelas, M.; Esteve-Zarzoso, B.; Mas, A.; Canals, J.M.; Zamora, F. Oenological consequences of sequential inoculation with non-Saccharomyces yeasts (Torulaspora delbrueckii or Metschnikowia pulcherria) and Saccharomyces cerevisiae in base wine for sparkling wine production. Eur. Food Res. Technol. 2015, 240, 999-1012. [CrossRef]

47. Mateo, J.J.; Maicas, S. Application of non-Saccharomyces yeasts to wine-making process. Fermentation 2016, 2, 14. [CrossRef]

48. Esteve-Zarzoso, B.; Manzanares, P.; Ramón, D.; Querol, A. The role of non-Saccharomyces yeasts in industrial winemaking. Int. Microbiol. 1998, 1, 143-148.

49. Fernández, M.; Úbeda, J.F.; Briones, A.I. Typing of non-Saccharomyces yeasts with enzymatic activities of interest in wine-making. Int. J. Food Microbiol. 2000, 59, 29-36. [CrossRef]

50. Verstrepen, K.J.; van Laere, S.D.M.; Vanderhaegen, B.M.P.; Derdelinckx, G.; Dufour, J.P.; Pretorius, I.S.; Winderickx, J.; Thevelein, J.M.; Delvaux, F.R. Expression levels of the yeast alcohol acetyltransferase genes ATF1, Lg-ATF1, and ATF2 control the formation of a broad range of volatile esters. Appl. Environ. Microbiol. 2003, 69, 5228-5237. [CrossRef]

51. López, M.C.; Mateo, J.J.; Maicas, S. Screening of $\beta$-glucosidase and $\beta$-xylosidase activities in four non-Saccharomyces yeast isolates. J. Food Sci. 2015, 80, C1696-C1704. [CrossRef]

52. Ruiz, J.; Kiene, F.; Belda, I.; Fracassetti, D.; Marquina, D.; Navascués, E.; Calderón, F.; Benito, A.; Rauhut, D.; Santos, A.; et al. Effects on varietal aromas during wine making: A review of the impact of varietal aromas on the flavor of wine. Appl. Microbiol. Biotechnol. 2019, 103, 7425-7450. [CrossRef]

53. Hernández, L.F.; Espinosa, J.C.; Fernández-González, M.; Briones, A. $\beta$-Glucosidase activity in a Saccharomyces cerevisiae wine strain. Int. J. Food Microbiol. 2003, 80, 171-176. [CrossRef]

54. Swangkeaw, J.; Vichitphan, S.; Butzke, C.E.; Vichitphan, K. The characterisation of a novel Pichia anomala $\beta$-glucosidase with potentially aroma-enhancing capabilities in wine. Ann. Microbiol. 2009, 59, 335-343. [CrossRef]

55. Gonzalez, R.; Quirós, M.; Morales, P. Yeast respiration of sugars by non-Saccharomyces yeast species: A promising and barely explored approach to lowering alcohol content of wines. Trends Food Sci. Technol. 2013, 29, 55-61. [CrossRef] 
56. Padilla, B.; Gil, J.V.; Manzanares, P. Challenges of the non-conventional yeast Wickerhamomyces anomalus in winemaking. Fermentation 2018, 4, 68. [CrossRef]

57. Mendes Ferreira, A.; Clímaco, M.C.; Mendes Faia, A. The role of non-Saccharomyces species in releasing glycosidic bound fraction of grape aroma components-A preliminary study. J. Appl. Microbiol. 2001, 91, 67-71. [CrossRef]

58. Hjelmeland, A.K.; Ebeler, S.E. Glycosidically bound volatile aroma compounds in grapes and wine: A review. Am. J. Enol. Vitic. 2015, 66, 1-11. [CrossRef]

59. González-Barreiro, C.; Rial-Otero, R.; Cancho-Grande, B.; Simal-Gándara, J. Wine aroma compounds in grapes: A critical review. Crit. Rev. Food Sci. Nutr. 2015, 55, 202-218. [CrossRef] [PubMed]

60. Cai, J.; Zhu, B.Q.; Wang, Y.H.; Lu, L.; Lan, Y.B.; Reeves, M.J.; Duan, C.Q. Influence of pre-fermentation cold maceration treatment on aroma compounds of Cabernet Sauvignon wines fermented in different industrial scale fermenters. Food Chem. 2014, 154, 217-229. [CrossRef]

61. Lambrechts, M.G.; Pretorius, I.S. Yeast and its importance to wine aroma-A review. S. Afr. J. Enol. Vitic. 2000, 21, 97-129. [CrossRef]

62. Kim, D.H.; Lee, S.B.; Jeon, J.Y.; Park, H.D. Development of air-blast dried non-Saccharomyces yeast starter for improving quality of Korean persimmon wine and apple cider. Int. J. Food Microbiol. 2019, 290, 193-204. [CrossRef]

63. Morata, A.; Loira, I.; Escott, C.; del Fresno, J.M.; Bañuelos, M.A.; Suárez-Lepe, J.A. Applications of Metschnikowia pulcherrima in wine biotechnology. Fermentation 2019, 5, 63. [CrossRef]

(C) 2020 by the authors. Licensee MDPI, Basel, Switzerland. This article is an open access article distributed under the terms and conditions of the Creative Commons Attribution (CC BY) license (http://creativecommons.org/licenses/by/4.0/). 